\title{
THE WORD 'ALLAH' AND ITS USAGE: AN ANALYSIS INTO THE HISTORY OF THE ARABIC LANGUAGE
}

\author{
Solehah Yaacob* \\ Arabic Department Language \& Literature \\ Kulliyyah of Islamic Revealed Knowledge \& Human Sciences, International Islamic University Malaysia \\ *Corresponding author: niknajah@iium.edu.my
}

\section{Article history}

Received: 2015-01-05

Received in revised form: 2015-10-18

Accepted: 2015-04-13

\begin{abstract}
The issue of the word 'Allah' is evidence that Malaysia's society is not yet deeply enlightened on the origins of the Arabic language, that is, the language of the Qur'an. To explain this issue in more details towards the origins of this language of the Qur'an, research on the word 'Allah' is sample proof that the nahw systems have been practiced, thus the word 'Allah' through an Arabic linguistic nahw approach has to be phrased to determine when did this word appear. Ibnu Manzur, in his book Lisaan al- Arab, had discussed the meaning of the word 'Allah' in depth. The word

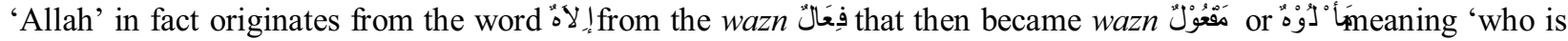
worshipped'. Sibawaih had also mentioned, in his book al-Kitab, that pre-Islamic Arabs had used the word " $\mathrm{y}$, with omission of the second 'Lam' in this word 'Allah'. This means that when the word "ע is perfect or complete in nominative rules it is pronounced as 'له ' where this is only used in the Qur'an. Therefore, Books before the Qur'an had not used the word 'aلال'. Thus research such as this one has to be discussed in details, since this word 'Allah' involves the Aqidah of the Muslim Ummah.
\end{abstract}

Keywords: Word "Allah”, Arabic Language, Arabic Literature

(C) 2014 Penerbit UTM Press. All rights reserved. 


\subsection{INTRODUCTION}

The issue of the word 'Allah' has still not settled down although the court has made a final decision on it. In order to clarify this word's issue in further details, a linguistic approach into Arabic grammar has to be argued. Ibnu Manzur, in his book Lisaan al- Arab, had discussed the meaning of the word 'Allah' in depth. The word 'Allah' (Ibn Manzur, Lisaan al-Arab, p. 7-10) in fact originates from the word "' إ from

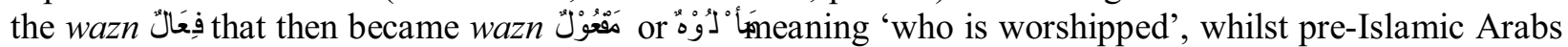
had used the word " 8 with omission of the second 'Lam' in this word 'Allah', because it has 3 'Lams, as in the analysis below:

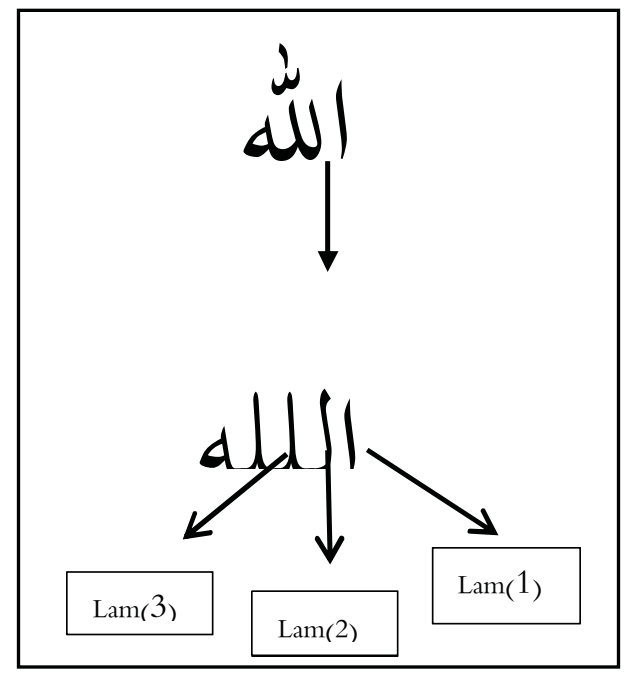

The first 'Lam' is known as Lam al-Ta'rif, meanwhile the second is Lam al-Jar. Thus it is clear that the original word is $\nabla$ because the third Lam is lengthened in pronunciation or madd. Whereas, " $" \mathrm{l}$ ! is when the Hamza (before the first Lam(1)) is maintained on the word when it undergoes idgham (Lam(2) i.e. Lam al-Jar is inserted into Lam(3) i.e. Lam al-Asal. Then it will appear as if there are only 2 Lams i.e. Lam (3) (Lam Asal) and Lam (1) (Lam al-Ta'rif that is also known as the Lam of definition/introduction). There are clear arguments about the difference of using 'Laahun' amongst the Pre-Islamic Arabs. It is related by Abu Zaid that al-Kisaai narrated to him:

$$
\text { لََٔتُ كتاباً في معاني القرآن، فقُلتُ له: أسمعتُ الحمدُ لاهِ ربِّ العالمين؟، فقال: لا، فقلتُ: أسمعها. }
$$

Meaning: (Al-Kisaai said, "I have composed a book on interpretations of the meanings of the Qur'an"; then Abu Zaid said, "I answered him, Alhamdu Laahi Rabbi al-Aalamin." Then al-Kisaai said, "No." "Then I further replied", said Abu Zaid, "I heard them (Pre-Islamic Arabs) say so")

(Ibn Manzur, Lisaan al-Arab p.9).

From this story, al-Azhari had emphasized that:

$$
\text { لايجوز في القر آن إلا الحمدلِّة بمُدّة اللام ، و إذّما يُقر اءُ ما حكاه أبو زيد الأعراب ومن لا يعرف سنة القرآن }
$$

Meaning:(It is not correct to use other words such as لإ, and so on, in the Qur'an APART FROM the word 'Allah' only, whereas the reading of Abu Zaid, 'لآل who do not know the correct technique of the Qur'an's norms)

(Ibn Manzur, Lisaan al-Arab, 9). 
This fact was affirmed by Abu al-Haytham who held the opinion that the word 'all' originates from 'إلاه'. As Allah (SWT) declares in al-Mu'minun, verse 91:

$$
\text { (ما اتخذ الله من ولا وما كان معه من إلـإذاً لذهب كل إله بما خلق ولعلا بعضهم على بعض سبحان الله عما }
$$

Al-Laithy is of the opinion that the word God of the Worlds is 'Allah' although in the above-

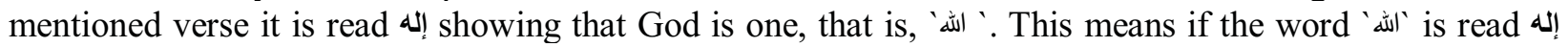
in any verse of the Qur'an, it means 'لاله ' that is the one God NOT the one used or meant by Pre-Islamic Arabs.

From the above explanation, it is clear that Pre-Islamic Arabs did not at all use the word all to call

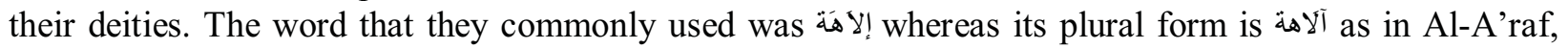
127:

$$
\text { (ويذرِك وآلِّهنَكَ ) }
$$

Whereas Ibn Abbas read it as: (ويذرك وإلاهنتك)(Ibn Manzur, Lisaan al-Arab, p. 9).

The alphabets that they used to refer to their deities also use the same alphabets as the word 'Allah' i.e. Lam (ل), Ha' (لهاء), Hamza (أل) and closed $\mathrm{Ta}^{\prime}$ '(ة) but this does not mean it has the same meaning as the word 'Allah'. This is because these alphabets can also be utilized to form other words

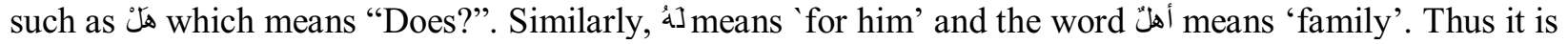
clear that such usage is something very common in the context of development of a language. Linguists contend that the smallest form of any language that is found on this planet is the sound and it is also known as phoneme. Here the author presents two samples of ancient writing. Below is a sample of 'Musnad writing' (www.qudamaa.com/vb/t19131.html) that was used by the Acadians of Iraq (the Mesopotamian valley):

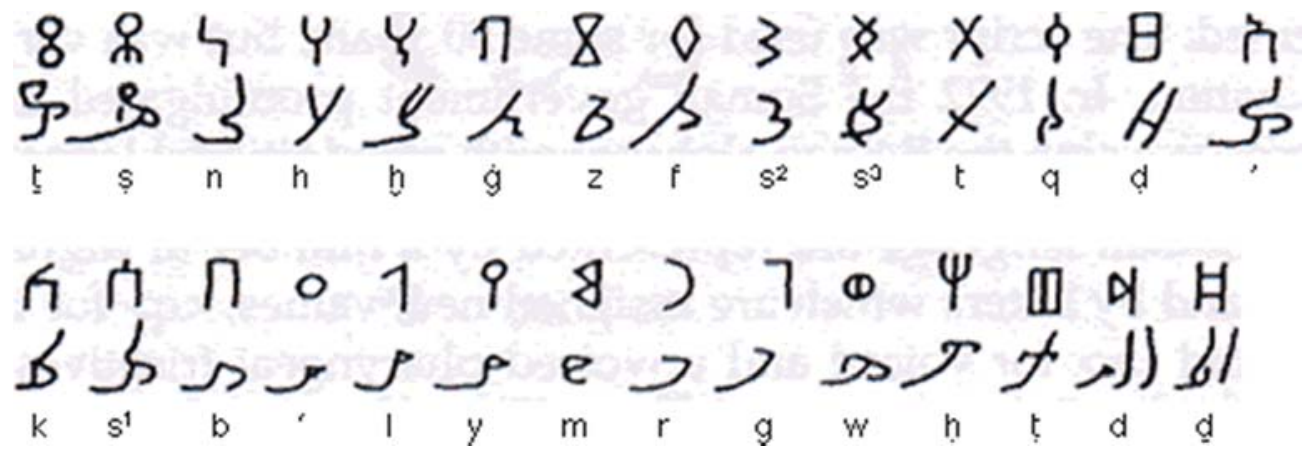

This, on the other hand, is 'Nabataean Writing' (www.qudamaa.com/vb/t19131.html) of Northern Mesopotamia:

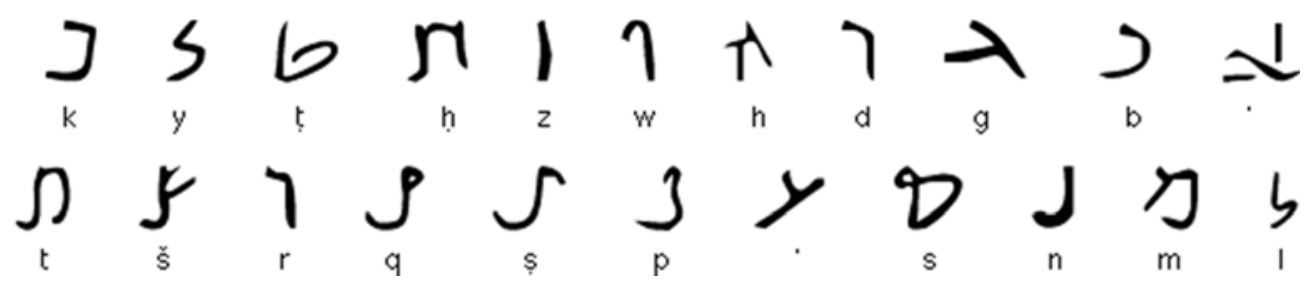

From this writing alone, it can be noted that the word 'له'l' is difficult to form, even if there is any form that is similar to it, it does not mean 'اله'. The following sample is one of the oldest writings of Arabic dated 267 A.D (http://www.hurras.org/vb/showthread.php): 

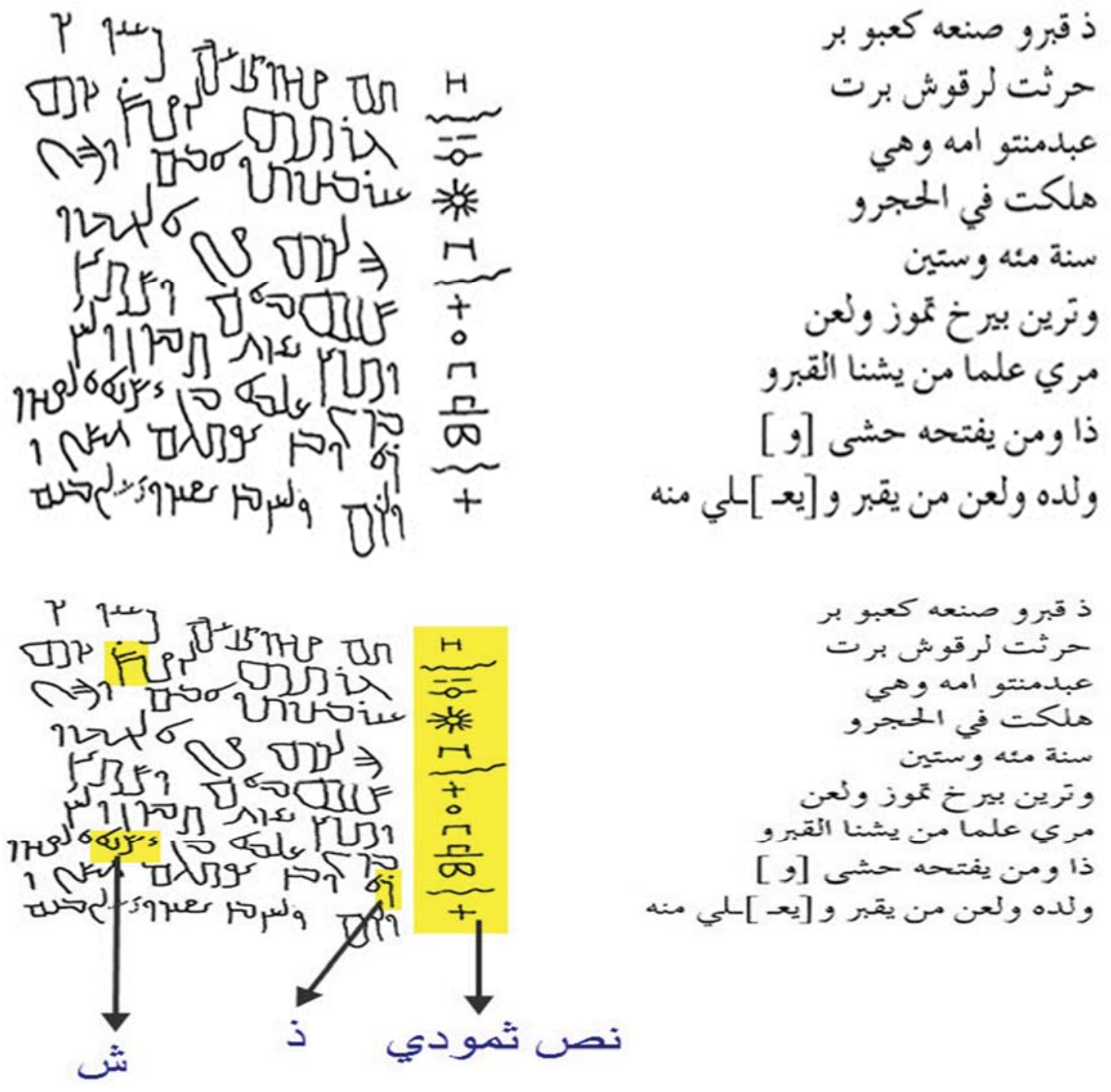

This is an original text of Imru' al-Qais that dates back to the third century (http://www.hurras.org/vb/showthread.php).

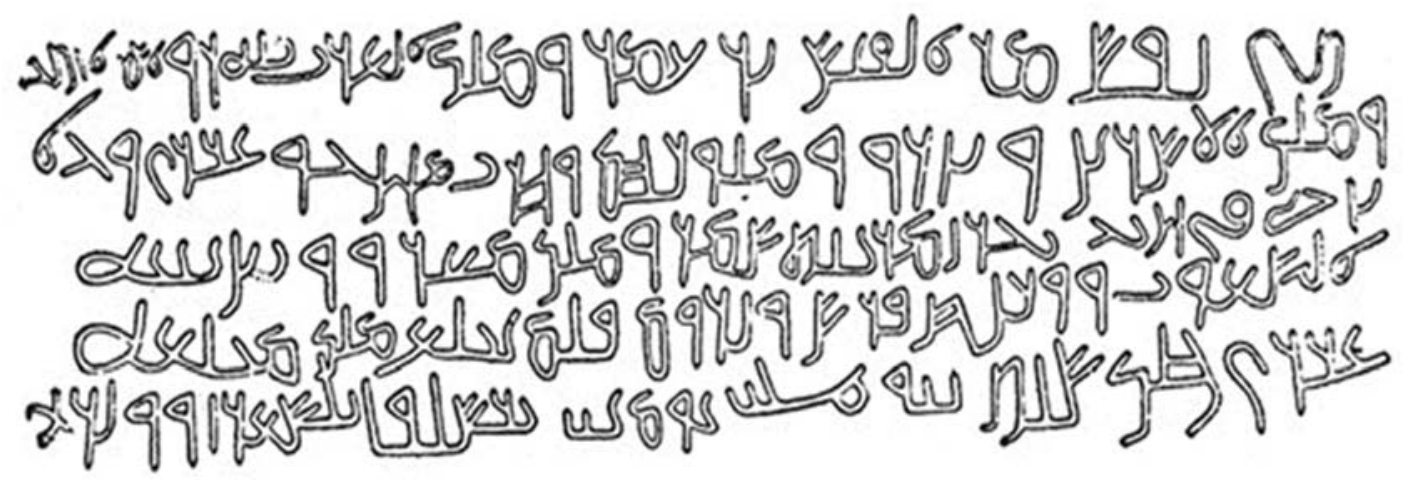

(هذا قبر امرئ القيس بن عمرو ملك العرب كلهم الذي تقلد التاج. واخضع قبيلتي أسد ونزار وملوكهم و هزم مذحج وقاد الظفر

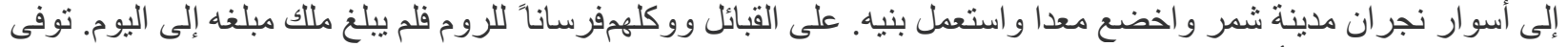

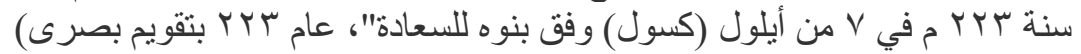


This text on the other hand is an original text of Ummu al-Jamal that dates to the $5^{\text {th }}$ century AD (http://www.hurras.org/vb/showthread.php):

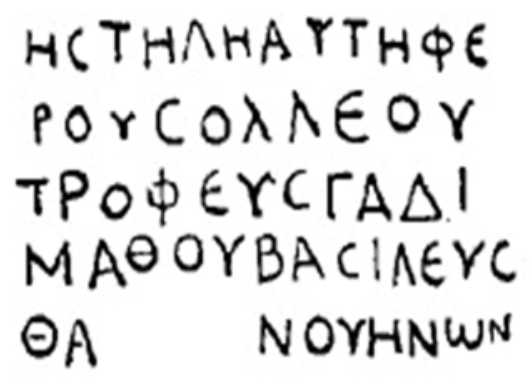

It can be seen that the words that resemble the word 'الله', in form, do not mean or refer to Allah. If so, how about the Pre-Islamic poetry, the majority of which used the word Allah? The author theorizes that the word الله that is written in those poems is a practice of the scribes who copied back the original poems, where these authors lived after the arrival of the Qur'an or the prophethood of Muhammad (SAW). There are also several questions that have arisen about the presence of several verses in the Qur'an that narrate how the people of Isa (PBUH) call him ابن الله (son of Allah), such as in al-Taubah, verse 30:

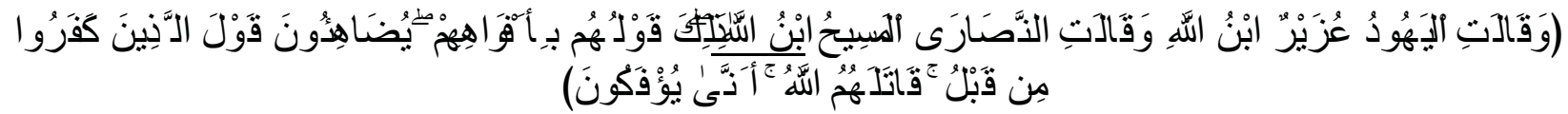

In fact, the word الله iاله is used in that verse because the Qur'an in itself was sent down in the Arabic language, and if it was mentioned in the Qur'an as ابن or ابن or or إبن or or إبن or or إبن or , it would not have been accurate from the perspective of the principles of Arabic nahw. This is because ابن is an Idafah technique that requires a nakirah noun and ma 'rifah. It is not refuted that there are also idafah techniques that can accept ma'rifah noun or nakirah on the two mentioned idafahs if one of these idafahs is made up of mushtaqaat, but not on the word ابن الله as the word is an original ma'rifah noun that does not arise from any verb or action. Thus following $n a h w$, it is not allowed to have a nakirah (Ibn Aqil, 1998) reading on the word اله

\subsection{ARAMAIC WAS THE LANGUAGE OF THE SCRIPTURES BEFORE QUR'AN}

If Pre-Islamic Arabs did not use the word all for their deities, how about the Psalms, Torah, and the Bibles and their use of the word wl ? It ought to be a general knowledge that these scriptures were revealed in Aramaic and not Hebrew or Greek. The Jewish people of that time had tried to mix Aramaic and Phoenician (i.e. the language of the Canaanite of Palestine) into their language as many Jewish people were scribes at that time (Majid Khair Bik, 1992). Aramaic is known in Arabic as الأرامية, this Aramaic is definitely the language that was used in the Psalms, Torah, and Gospels, which had experienced several changes from the angle of language usage because these books were not revealed to the same people, but to people who were from a different era. Thus, there exist differences from the aspect of pronunciation and writing because what changed is only the dialect whereas the language remains the same i.e. Aramaic. When seen from a wider scope, Aramaic originates from the noun 'Aram' which is the name of a son of Sam bin Nuh (Jawad, 1972). The name 'Aram' is also an old name for the city of Damascus (Damashq) or its original pronunciation Dar Mashqi (Majid Khair Bik, 1992). This explains to us that Damascus was the city of the Aramaic language (Taha, 1956). 
Western scholars believe that because the Holy scriptures (with the exception of the Qur'an) were revealed in Aramaic, then it must have been the lingua franca amongst the communities of that time which is also the origin of the Hebrew language. In fact this statement is rather loose since Hebrew is a combination of Aramaic and Phoenician (the language of the Canaanites who were the original inhabitants of Palestine). The Jewish people, who only appeared around 2000 years BC had migrated from their original place i.e. near the desert of Jordan heading towards Palestine which was at that time was inhabited by Bani Israel (Israelites) and the Canaanites (Israel is the other name of the prophet Jacob (PBUH), whereas Bani means 'children of') and Canaan was a tribe that is believed to worship idols. The Jewish saw that in order to get an opportunity to get a place in that community they have to have their own identity, that is by merging the two languages (Aramaic and Phoenician) with their own language (Solehah, 2014). This is because Aramaic, Babylonian Accadian, Sumerian and Phoenician were acknowledged languages of those previous nations. The clear argument for that is the discovery of cuneiforms (on tablets) of the Epic of Gilgamesh, dating 4000 years BC, which is believed to be the oldest to contain Accadian Babylonian writing (Taha, 1952). It is the tale of a king named Gilgamesh that is about 3000 cuneiforms that were found in Mesopotamia by an Englishman named George Smith in 1873 (Kramer, 1959). He notes that of the 3000 tablets that he had found, it is the Epic of Gilgamesh that is most complete, from the aspect of its narration.

This tablet had mentioned the Great flood of Noah, for example the king mentions 'My grandfather had built a very big ship because there was big flood, and the name of my grandfather is Utu Nabishteem' (Taha, 1952). Upon analysis, this fact is not far in meaning from The Flood that is mentioned in the Torah except that the person who built the big ship is different; in the Torah he is called Noah. It is clear that the stories are similar but with different names; this is probably due to the differing dialects or titles that were given to the person based on the thinking of the people based on their time and location. Despite that, Western scholars do not recognize the Epic of Gilgamesh as the oldest document in the world as for them it is the Iliad and Odyssey that was written by Homer around BC that is the oldest. However, this attitude of the Western scholars was criticized by Professor B. Landsberger, an expert on the world's oldest languages in 1958 during the seventh conference on languages of cuneiforms that was held in Paris (Ibid, 1952). He said that it is time that the West recognizes the Epic of Gilgamesh as the oldest reference material in the world, and not the Iliad and the Odyssey by Homer. If seen for a cursory moment, the harmony of the poems that are in the Iliad and Odyssey is similar to the technique of harmony found in Arab poetry. In addition, in the early stages of the poetry in the Iliad and Odyssey, it was without writing and was memorized just like the pre-Islamic poetry (Powell, 1991: 9-15, 187-189). This situation was further affirmed by a statement by Professor Barry B. Powel, who in his book 'Homer and the Origin of Greek Alphabet' mentions that original Greek writing originates from Palestine i.e. it is influenced by the Phoenician language that was used by the Canaanites (Margoliouth,1924: 11).

The evidence that was observed, according to this professor, is that in the beginning Greek was written from right to left and then it was changed to left to right as it is now. Apart from that, Greek also has pronunciations such as the letter Ain's pronunciation whereas this is not found in any of the other Indo-European languages (Powell, 1991: 9 - 15). Professor Taha Baqir, the first Arab who attempted to translate the Epic Gilgamesh to Arabic in 1953 (Taha, 1952), contends that translation of the Babylonian Accadian to Arabic is much easier and faster than its translation to English as the harmony in the Accadian Babylonian writing in the 'Epic of Gilgamesh' uses similar techniques as in Arabic such as muthanna (for things that are two), Jama' (plural), muzakkar (masculine), muannath (feminine) as well as the use of dhameer (pronouns) (Taha, 1952; Majid Khair Bik, 1992; Beeston, 1983: 1; Roux, 1965: 124). Apart from that, King Hammurabi's tablet that is known as 'Hammurabi's Code' (Jurji, 1911) dating $1800 \mathrm{BC}$ was also written in the Accadian Babylonian writing where the information in it is sufficient evidence that government under the leadership of King Hammurabi was advanced. As an example, schooling systems for children were discussed in this code, and furthermore Hammurabi's code also held women at an esteemed position by giving them a chance to work apart as well as protects their honor. It is so advanced that some Western scholars think that the Ten Commandments of Moses (The Tablets of Stone) are influenced by Hammurabi's code that appeared 800 years before it (Majid Khair Bik, 1992). 
From the discussed researches, it is thus clear Aramaic was not the lingua franca for the ancient communities, as there were languages that were more widely used in the government administrations of that time. Therefore, usage of Aramaic in the Psalms, Torah and Gospels or any of the scriptures of the Jewish people such as the Talmud is in fact a usage of a language that is isolated i.e. they are to be used for that race's people alone. It is also essential to remember that every language has to undergo processes, little by little, in order to become a harmonious form of the perfect language because the language has the characteristic of being 'incomplete rules' in its original stage, whether in terms of pronunciation or writing development. This is because language development must be based on the development of the thinking of that particular race (Solehah, 2013).

\subsection{THE PROCESS OF WRITING ELOQUENT ARABIC}

Complete writing of eloquent Arabic began at the time of the fourth Rightly-guided Caliph that is during the governance of Ali bin Abi Talib when he requested Abu al-Aswad ad-Duali (Died $69 \mathrm{H}$ ) to create a writing system in order to prevent Arabic mistakes. Such was his instruction to his scribe from the clan of Bani Abdu Qafsi (As-Sirafi, 1985):

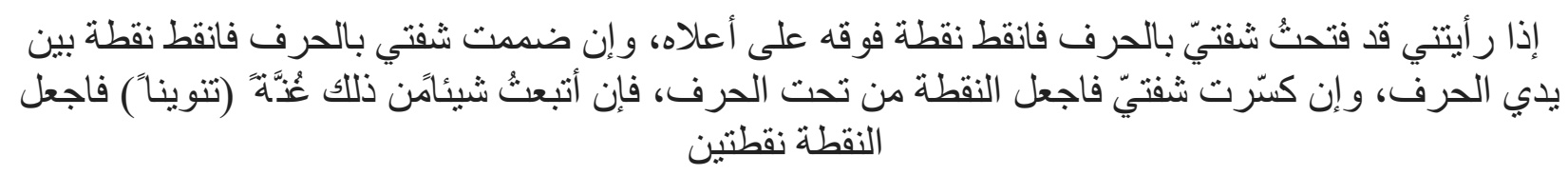

Which means: 'If you see me literally opening my lips, then place a dot on top, and if I literally merge my lips, then place a dot in the center between the top and bottom lines, and if I read with my lips drawn apart downwards, then place a dot from below the alphabet, and if I follow that to another word by Ghunnah (tanween) then you make the dot into two dots'.

This system was invented by Abu al-Aswad ad-Duali because grammatical mistakes in Arabic at that time were a big calamity to the Arabs so much so that Hajjaj Yusof as-Thaqafi (As-Sirafi, 1985), a great linguist, had made an Arabic grammatical mistake while reading at-Taubah, verse 24:

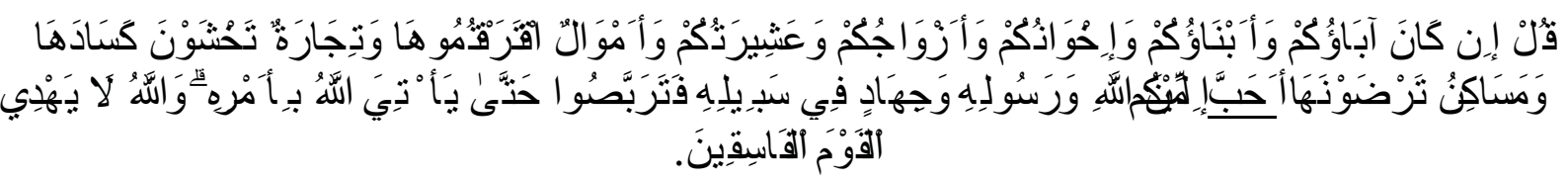

The underlined word, أ was marfu'ah (in nominative form) that is it was read with a dhommah i.e. كhen it should be read with a fathah because it is the khabar of the beginning of that sentence. From this, it can be understood that grammatical mistakes occurred because there was no complete writing system like that in the era of Khalil Ahmad al-Farahidi (died $117 \mathrm{H}$ ). The time before Khalil is the time of the Qurra' who had put reading signs whether in the alphabets in the form of dots (vowels) or putting reading signs at the end of Arabic words to differentiate between fathah, kasrah, dhommah, tashdid or sukoon (As-Sirafi, 1985). If this was the situation, this means that the writing during

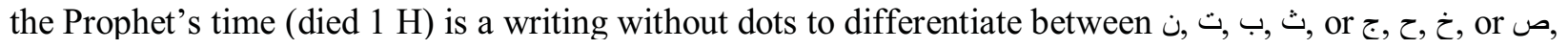
ض, or $\omega$, or $د, \dot{\jmath}, j$ or $\dot{\omega}, \dot{\omega}$, and these alphabets are known as Huruf Mu'jamah, whereas the rest of the alphabets are known as Huruf Muhmalah, such as $\mathrm{J}, \mathrm{l}$, , , , ك, and g.

It is clear that the Arabic writing was incomplete before the time of Ali Ibn Abi Talib, moreover the methods of Arabic writing and its nahw were only officially perfected during the eras of the Qurra' or tabi tabi'een. The person who first introduced the concept of Qiyas in Arabic nahw is Abu Ishak alHadrami (Died $117 \mathrm{H}$ ), that is, after the death of Abu Aswad ad-Duali then Abu Ishak al-Hadrami was born (Solehah, 2014). Shawqi Daif, a famous writer from Egypt had disputed the statements of the narrators who said that Ali Ibn Abi Talib is the one who had created Arabic nahw and its writing. He sees this view as propaganda of the Shiites to further elevate the status of Ali Ibn Abi Talib (Solehah, 2014). 
He views that Ali Ibn Abi Talib would not have had sufficient time to think about creating a method of writing and the Arabic grammar as he would have been too preoccupied with national matters such as training the army for war, settling the problems of the Khawarij, and the matter of widening the borders. If pondered upon, it is rather unreasonable that Ali could be the one who invented the nahw principles and its writing. Further, Abu Aswad ad-Duali who was the judge and a linguist of Basrah at that time had only time to spark the idea of putting dots on every Mu'jamah alphabet and dots on every Arabic word to indicate only whether it is read with kasrah, fathah, or dhommah or sukoon (Solehah Yaacob, 2014), while the works to perfect the principles of nahw and complete writing were done by his students.

\subsection{CONCLUSION}

From the above explanation, it is clear to us that complete Arabic writing did not exist at the time of the Prophet Muhammad (SAW), and not even during the time of the Rightly-guided Caliphs. If that is so, then how is it possible that the word 'Allah' was used by pre-Islamic Arabs when it is a noun that is published exclusively for the Qur'an and just a product of professional memorizers when there was no writing at its early stage? It is clear thus that the word 'Allah' is reserved for the people who worship Islam only.

\section{References}

As-Sirafi. (1985). Akhbar an-Nahwiyyina al-Basriyiina. Edited by Muhammad Ibrahim al-Banna. Cairo: Dar al-Usama`.

Beeston, A. F. L. (1983). The Evolution of the Arabic Language, in the book Arabic literature to the End of the Umayyad period.

Georges Roux. (1965). Ancient Iraq, London: George Allen and Unwin LTD. Available at: http://www.hurras.org/vb/showthread.php. Access date: 28/2/2014.

Ibn Aqil. (1998). Sharh Ibn Aqil. Edited by Yusuf al-Sheikh Muhammad al-Baqaie, Vol 2. Al-Idafah Chapter. Beirut: Dar al-Fikr.

Jawad, A. (1972). Al-Mufassal Fi Tarikh al-Arab Qabla al-Islam, Vol. 1. Beirut: Dar al-Ilmi Lil Malaayiin.

Jurji Zaydan (1911). Tarikh Adab al-Lughah al-Arabiyah. Cairo: Dar al-Hilal.

Kramer, S. N. (1959). History Begins at Sumer. New York: Doubleday \& Company, Inc.

Majid Khair Bik (1992). Al-Lughah al-Arabiyah Juzuruha, Intisharuha, Ta siruha Fi as-Sharqi Wa alGharbi. Damascus: Dar Sa adu al-Din.

Margoliouth, (1924). The Relations between Arabs and Israelites Prior to the Rise of Islam. London: Oxford University.

Powell, B. B. (1991). Homer and the Origin of the Greek Alphabet. London: Cambridge University Press.

Solehah Yaacob (2014). Kefahaman nahu Arab dan sejarah perkembangannya dalam menentukan penggunaan kalimah Allah. E-Journal Practice \& Information Technology, Vol. 1. E-ISSN: 22877445.

Available

at: http://worldconferences.net/journals/glit/papericssr/GL\%20072\%20Solehah\%20Yaacob.pdf.

Solehah Yaacob. (2013). Linguistic argumentation and logic: an alternative method approach in Arabic grammar. Argument: Biannual Philosophical Journal, Poland, 3(2), 407- 430.

Solehah Yaacob. (2014). Arabic Language is the Foundation of Sematic Languages, Arab World English Journal, Arab Society of English Language Studies Publication, Vol. 5. USA. Available at: 
Solehah Yaacob/ UMRAN - International Journal of Islamic and Civilizational Studies. vol. 2, no. 3 (2015) 46-54

http://awej.org/index.php?option=com content\&view=article\&id=534:solehahyaacob\&catid=51\&Ite $\underline{\mathrm{mid}}=152$

Taha Baqir (1952). Malhamah al-Gilgamesh: The Oddesy of Ancient Iraq. E-Book available at: www. AOlaf.com, 85-104.

Taha Baqir (1956). Wadi an-Nil, Amman: Al-Warraq Lil Nashar,1956, pp. 271-272. Available at: www.qudamaa.com/vb/t19131.html. Access Date: 28/2/2014. 